\title{
Temperature Dependence of Primary Species G(values) Formed from Radiolysis of Water by Interaction of Tritium $\beta^{-}$Particles
}

\author{
Sofia Loren Butarbutar ${ }^{*}$, Sriyono, and Geni Rina Sunaryo \\ Center for Nuclear Reactor Technology and Safety, BATAN, Building 80 Puspiptek Area, Serpong, Tangerang Selatan, Indonesia
}

\begin{tabular}{l}
\hline ARTICLE INFORMATION \\
\hline Article History: \\
Received: \\
02 December 2016 \\
Received in revised form: \\
22 February 2017 \\
Accepted: \\
13 June 2017 \\
\hline
\end{tabular}

Keywords:

Monte Carlo simulation

Tritium $\beta$ electron

$\gamma$-ray ${ }^{60} \mathrm{Co}$

Water radiolysis

$\mathrm{G}$ (values)

\begin{abstract}
TEMPERATURE DEPENDENCE OF PRIMARY SPECIES G(VALUES) FORMED FROM RADIOLYSIS OF WATER BY INTERACTION OF TRITIUM $\beta$-PARTICLES. G(values) are important to understand the effect of radiolysis of Nuclear Power Plant (NPP) cooling water. Since direct measurements are difficult, hence modeling and computer simulation were carried out to predict radiation chemistry in and around reactor core. $\mathrm{G}$ (values) are required to calculate the radiation chemistry. Monte Carlo simulations were used to calculate the $\mathrm{G}$ (values) of primary species $e_{a q}^{-}, \mathrm{H}^{\circ}, \mathrm{H}_{2},{ }^{\circ} \mathrm{OH}$ dan $\mathrm{H}_{2} \mathrm{O}_{2}$ formed from the radiolysis of tritium $\beta$ low energy electron. These radiolytic products can degrade the reactor components and cause corrosion under the reactor operating conditions. $\mathrm{G}$ (values) prediction can indirectly contribute to maintain the material reliability. $\mathrm{G}$ (values) were calculated at $10^{-8}, 10^{-7}, 10^{-6}$ and $10^{-5} \mathrm{~s}$ after ionization at temperature ranges. The calculation were compared with the $\mathrm{G}$ (values) of $\gamma$-ray ${ }^{60} \mathrm{Co}$. The work aimed to understand temperature effect on the water radiolysis mechanism by the tritium $\beta$ electron. The results show that the trend similarity was found on the temperature dependence of $\mathrm{G}$ (values) of tritium $\beta$ electron and $\gamma$-ray ${ }^{60} \mathrm{Co}$. For tritium $\beta$ electron, $\mathrm{G}$ (values) for free radical were lower than $\gamma$-ray ${ }^{60} \mathrm{Co}$, but higher for molecular products as temperature raise at $10^{-8}$ and 10 ${ }^{7}$. The significant differences for these two type of radiations were on $\mathrm{G}\left(\mathrm{H}_{2}\right), \mathrm{G}(\mathrm{OH})$ and $\mathrm{G}\left(\mathrm{H}^{*}\right)$ at $10^{-6}$ and $10^{-5} \mathrm{~s}$ above $200^{\circ} \mathrm{C}$.
\end{abstract}

\begin{abstract}
ABSTRAK
KETERGANTUNGAN TEMPERATUR DARI G (VALUES) SPESIES PRIMER YANG TERBENTUK DARI RADIOLISIS AIR DENGAN INTERAKSI PARTIKEL $\boldsymbol{\beta}$ - TRITIUM. G (values) penting untuk mengetahui efek dari proses radiolisis air pendingin reaktor pembangkit listrik tenaga nuklir (PLTN). Karena pengukuran konsentrasi kimia secara langsung pada reaktor sangat sulit maka dilakukan pemodelan dan simulasi untuk memprediksi kimia radiasi di teras reaktor. Simulasi Monte Carlo digunakan untuk menghitung $\mathrm{G}$ (values) dari spesies primer $\mathrm{e}_{\mathrm{aq}}^{-}$, $\mathrm{H}^{\circ}, \mathrm{H}_{2},{ }^{\circ} \mathrm{OH}$ dan $\mathrm{H}_{2} \mathrm{O}_{2}$ yang terbentuk dari radiolisis elektron $\beta$ energi rendah tritium. Produk radiolisis ini dapat menurunkan komponen - komponen reaktor dan menyebabkan korosi pada kondisi operasi reaktor. Prediksi G (values) secara tidak langsung dapat berkontribusi untuk menjaga keandalan material. $\mathrm{G}$ (values) dihitung pada $10^{-8}, 10^{-7}, 10^{-6}$ dan $10^{-5}$ detik setelah ionisasi pada rentang temperatur. Hasil perhitungan dibandingkan dengan data $G$ (values) sinar $\gamma^{60} \mathrm{Co}$. Penelitian ini bertujuan untuk memahami pengaruh temperatur pada mekanisme radiolisis air oleh elektron $\beta$ energi rendah tritium. Hasil simulasi menunjukkan bahwa ada kemiripan tren antara ketergantungan temperatur berbagai $\mathrm{G}$ (values) hasil radiolisis air oleh elektron $\beta$ energi rendah tritium dengan sinar $\gamma^{60} \mathrm{Co}$. Hasil radiolisis air oleh elektron $\beta$ energi rendah tritium, dengan kenaikan temperatur pada $10^{-8}$ dan $10^{-7}$ detik, $G$ (values) radikal bebas lebih rendah dibandingkan dengan sinar $\gamma^{60} \mathrm{Co}$ sedangkan molekularnya lebih tinggi. Perbedaan signifikan antara kedua jenis radiasi ini adalah pada $\mathrm{G}\left(\mathrm{H}_{2}\right), \mathrm{G}\left({ }^{\circ} \mathrm{OH}\right)$ dan $\mathrm{G}\left(\mathrm{H}^{\circ}\right)$, pada $10^{-6}$ dan $10^{-5}$ detik untuk temperatur di atas $200^{\circ} \mathrm{C}$.
\end{abstract}

Kata kunci: simulasi Monte Carlo, $\beta$ electron tritium, sinar $\gamma^{60} \mathrm{Co}$, radiolisis air, $G$ (values)

\section{INTRODUCTION}

Most of current commercial power reactors use light water $\left(\mathrm{H}_{2} \mathrm{O}\right)$ as reactor coolant and neutron moderator, e.g. Pressurized Water Reactor, PWR. The primary coolant of PWR operates at pressure of $\sim 7-15$ $\mathrm{MPa}$ and temperature of $\sim 275-325^{\circ} \mathrm{C}^{[1]}$. The

*Penulis korespondensi.

E-mail: sofia@batan.go.id water is circulated in the reactor core and irradiated by mixture of radiation sources like fast electron, ${ }^{60} \mathrm{Co}$ gamma source, and also fast neutron which each source have typical linear energy transfer (LET). LET is defined as the energy disposed per unit length in the interval of $0.3-60 \mathrm{keV} / \mathrm{\mu m}^{[2,3]}$. This phenomenon initiates water chemistry decomposition or radiolysis process that form free radicals such as $e_{a q}^{-}, \mathrm{H}^{*},{ }^{\circ} \mathrm{OH}, \mathrm{HO}^{-} / \mathrm{O}^{-}$and 
molecular product such as $\mathrm{H}_{2}$ and $\mathrm{H}_{2} \mathrm{O}_{2}$. Those products can induce corrosion on the reactor core component and its piping related ${ }^{[2]}$. Corrosion problem cause the increase operation and maintenance cost, radioactivity contaminant, and radiation exposure risk to the worker. The optimization of water chemistry controls play a role in minimizing the material corrosion and its consequences to the power reactor.

The knowledge of water radiolysis process in nuclear reactor is important to control coolant water chemistry ${ }^{[4]}$. The most important parameters to evaluate chemical effect of water caused by ionic irradiation are $\mathrm{G}$ (values) of radiolytic products and reaction rate constants of all possible reaction between species. G(values) is defined as the number of molecule which is formed or decomposed per $100 \mathrm{eV}$.

For nuclear reactors which use heavy water as coolant, tritium $\left({ }^{3} \mathrm{H}\right.$ or $\left.\mathrm{T}\right)$ is an interesting phenomenon, since they produced relatively large amount of tritium caused by neutron activation of deuterium in water. Water with tritium is chemically marked as ${ }^{3} \mathrm{HO}^{2} \mathrm{H}$. Taking into account the radiolytical properties of water tritium and its influence to the material corrosion, investigating the influence of water marked with tritium in light water reactors is essential.

The G(values) information of ${ }^{60} \mathrm{Co} \gamma$ ray at high temperature measured by using chemical reaction combination and pulse radiolysis is largely available $e^{[5,6,7]}$, however there is no available information of water radiolysis using low energy $\beta$ electron at high temperature. Direct observation or chemical measurements in the reactor core is very difficult to perform due to high temperature and pressure as well as the field of various types of radiation. Therefore, models and simulations of chemical phenomena of water radiolysis by using computer code is the right choice. Monte Carlo simulation is suitable to describe the stochastic properties of the series of events that are generated after the ionizing radiation absorption by reactor water coolant. Monte Carlo computer code has been used to simulate the detailed water radiolysis interaction of $\gamma$ rays, fast neutrons at low temperatures and low energy electrons of tritium at room temperature and in the area of super critical water ${ }^{[1,8,9,10,11]}$, but interaction model of low energy electrons of tritium in water at high temperatures has not been done. In addition, this code has been used to calculate the G(values) for low energy electrons of tritium in water at room temperatures. The purpose of this study was to understand the temperature effect on water radiolysis mechanism by interaction low energy of electron $\beta$ tritium, using a Monte Carlo simulation to calculate $\mathrm{G}$ (values) primary species $e_{a q}^{-}, \mathrm{H}^{*}, \mathrm{H}_{2},{ }^{\circ} \mathrm{OH}$ and $\mathrm{H}_{2} \mathrm{O}_{2}$ ).

\section{METHODOLOGY}

Monte Carlo has been used to simulate detailed water radiolysis caused by interaction $\gamma$ rays, fast neutrons, and electrons of a low energy tritium ${ }^{[9.11,12]}$. Monte Carlo simulation can be used to describe the stochastic properties of the series of events that are generated after the absorption of ionizing radiation by reactor water coolant. Water radiolysis modeling by low energy electrons of tritium were performed using the Monte Carlo, that consists of two codes IONLYS and

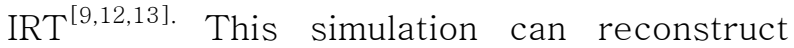
events that are very complex due to radiation deposit into the water coolant. Therefore, a detailed description of the Monte Carlo approach in the modelling stage of physics, chemical physics water radiolysis of various ionizing radiation have been published previously, thus only a brief description of the important features that will be presented in this paper. IONLYS program modelled events occure on chemistry-physics stage and radiation physics until the time of $10^{-12}$ second. IONLYS consists of two modules, namely TRACEPR to bring primary electron and TRACELE to bring secondary electrons to ionize the water until it reaches the electron thermal conditions ${ }^{[14]}$. In this study, the TRACEPR module is used to simulate the track of the electron results from tritium decay and simulate phenomena radiololysis causes. Outcomes of the TRACELE program in the form of early species such as $\mathrm{H}+,{ }^{\circ} \mathrm{OH}$, $\mathrm{H}^{*} \mathrm{OH}^{-}, \mathrm{H}_{2}, \mathrm{H}_{3} \mathrm{O}^{+}$, etc. used directly input into the chemical phases being modeled by the IRT program.

At this stage, the initial species randomly diffuse and react with each other 
according to the diffusion coefficient and reaction rate coefficients. As with the IONLYS, this program implements the method of "independent reaction times (IRT)", which is a technique that simulates reaction time without having to follow the trajectory of the diffusing species. Implementation of this program are described more detail in previous studies ${ }^{[9-11]}$. The reactions that occur in the process of radiolysis used in IONLYS and IRT program can be seen in Table 1. The information contained in this table is the values that are recommended to be used in modeling the water radiolysis at high temperatures. To see the effect of radiation by particles ${ }^{3} \mathrm{H} \beta$ - each simulation involving $\sim 6000$ different trajectory for statistical reasons and to mitigate the deviation data (the comparison with lower and higher trajectory numbers have been conducted, the results are not shown). In addition, the study is assumed that the concentration of water marked with tritium are small so the effect of the dose rate can be ignored.

Table 1. The main reactions used in IONLYS-IRT program $^{[15,18]}$

\begin{tabular}{|c|c|}
\hline Symbol & $k\left(M^{1} \mathrm{~s}^{-1}\right)$ \\
\hline $\mathrm{e}^{-}{ }_{\mathrm{aq}}+\mathrm{H}^{+} \rightarrow \mathrm{H}^{\cdot}$ & $3 \times 10^{12}$ \\
\hline $\mathrm{e}_{\mathrm{aq}}^{-}+\cdot \mathrm{OH} \rightarrow \mathrm{OH}^{-}$ & $4.5 \times 10^{11}$ \\
\hline $\mathrm{e}_{\mathrm{aq}}^{-}+\mathrm{H}^{\cdot}\left(+\mathrm{H}_{2} \mathrm{O}\right) \rightarrow \mathrm{H}_{2}+\mathrm{OH}^{-}$ & $3.5 \times 10^{11}$ \\
\hline $\mathrm{e}_{\mathrm{aq}}^{-}+\mathrm{H}_{2} \mathrm{O}_{2} \rightarrow \mathrm{OH}+\mathrm{OH}^{-}$ & $4.7 \times 10^{11}$ \\
\hline $\mathrm{e}_{\mathrm{aq}}^{-}+\mathrm{e}_{\mathrm{aq}}^{-}\left(+2 \mathrm{H}_{2} \mathrm{O}\right) \rightarrow \mathrm{H}_{2}+2 \mathrm{OH}^{-}$ & $4.2 \times 10^{8}$ \\
\hline $\mathrm{H}^{\cdot}+\mathrm{H}_{2} \mathrm{O} \rightarrow{ }^{\circ} \mathrm{OH}+\mathrm{H}_{2}$ & $2.2 \times 10^{5}$ \\
\hline $\mathrm{H}^{\cdot}+{ }^{\cdot} \mathrm{OH} \rightarrow \mathrm{H}_{2} \mathrm{O}$ & $4.4 \times 10^{10}$ \\
\hline $\mathrm{H}^{*}+\mathrm{H}^{\cdot} \rightarrow \mathrm{H}_{2}$ & $1.5 \times 10^{11}$ \\
\hline$\cdot \mathrm{OH}+\cdot \mathrm{OH} \rightarrow \mathrm{H}_{2} \mathrm{O}_{2}$ & $8.5 \times 10^{9}$ \\
\hline $\mathrm{H}^{+}+\mathrm{HO}_{2}^{-} \rightarrow \mathrm{H}_{2} \mathrm{O}_{2}$ & $1.2 \times 10^{12}$ \\
\hline
\end{tabular}

\section{RESULTS AND DISCUSSIONS}

The calculation result of $G$ (values) primary species by the interaction of reactor coolant water with low-energy electrons tritium $\beta$ can be seen in Figure 1. The results of $G$ (values) species radiation by Tritium $\beta^{-}$ particles with G(values) low-LET radiation $\left({ }^{60} \mathrm{Co} \gamma\right.$-rays) at $10^{-8}$ and $10^{-7}$ seconds tends to have a similarity, but there is a difference for $G\left(\mathrm{H}_{2}\right), G\left({ }^{*} \mathrm{OH}\right)$ and $G\left(\mathrm{H}^{*}\right)$ from both of radiation sources at $10^{-6}$ and $10^{-5}$ seconds. $\mathrm{G}$ (values) at low-LET radiation is obtained on the spur life time, it is the time required before spur overlap one another. For ${ }^{3} \mathrm{H}^{-}$ particle radiation with $G$ (values) for free radicals is lower than low-LET radiation but $\mathrm{G}$ (values) for molecular products is higher. These results reflect the character of LET ${ }^{3} \mathrm{H}$ $\beta^{-}$particles higher than ${ }^{60} \mathrm{Co} \gamma$ rays ${ }^{[14]}$. It is caused by a type of low-LET radiation $\left({ }^{60} \mathrm{Co}\right.$ $\gamma$-rays and fast electrons) that deposit energy on the relatively long distance between the two spurs as compared to the high-LET (low energy proton and ${ }^{3} \mathrm{H} \beta^{-}$particle). The spur will grow due to the interactions between radical species that form a molecular product affected in both of the adjacent spur to create homogeneous conditions. High-LET radiation types will deposit energy on the closer spur, so the potential interactions between radical species are higher. The effect of this interaction will generate higher molecular products.

The $e_{a q}^{-}$is one of the reducing species formed in radiolysis. For all the time evolution, $\mathrm{G}\left(e_{a q}^{-}\right)$decreases with increasing temperature (Figure 1). It is caused by a reaction of $e_{a q}^{-}$with $\mathrm{H}^{+}$ions and ${ }^{\circ} \mathrm{OH}$ based on the reaction (R1) and (R2).

$$
\begin{aligned}
& e_{a q}^{-}+\mathrm{H}^{+} \rightarrow \mathrm{H}^{\cdot} \\
& e_{a q}^{-}+{ }^{\cdot} \mathrm{OH} \rightarrow \mathrm{OH}^{-}
\end{aligned}
$$

Figure 1(a) shows a tendency that decay rate of these species faster than the rate of formation. This condition is proved by the amount of $e_{a q}^{-}$reduced or finished at the time of $10^{-5}$ seconds. Figure 2 shows time evolution of $e_{a q}^{-}$decay. $e_{a q}^{-}$decay is faster at higher temperature, due to reaction R1 and R2 occur more rapidly at high temperatures. This phenomenon indicates that the reaction rate constant is a parameter that sensitive to the increasing of temperature. At temperatures higher than the operating temperature, these free radicals are no longer found because they have reacted with other reactive species. 

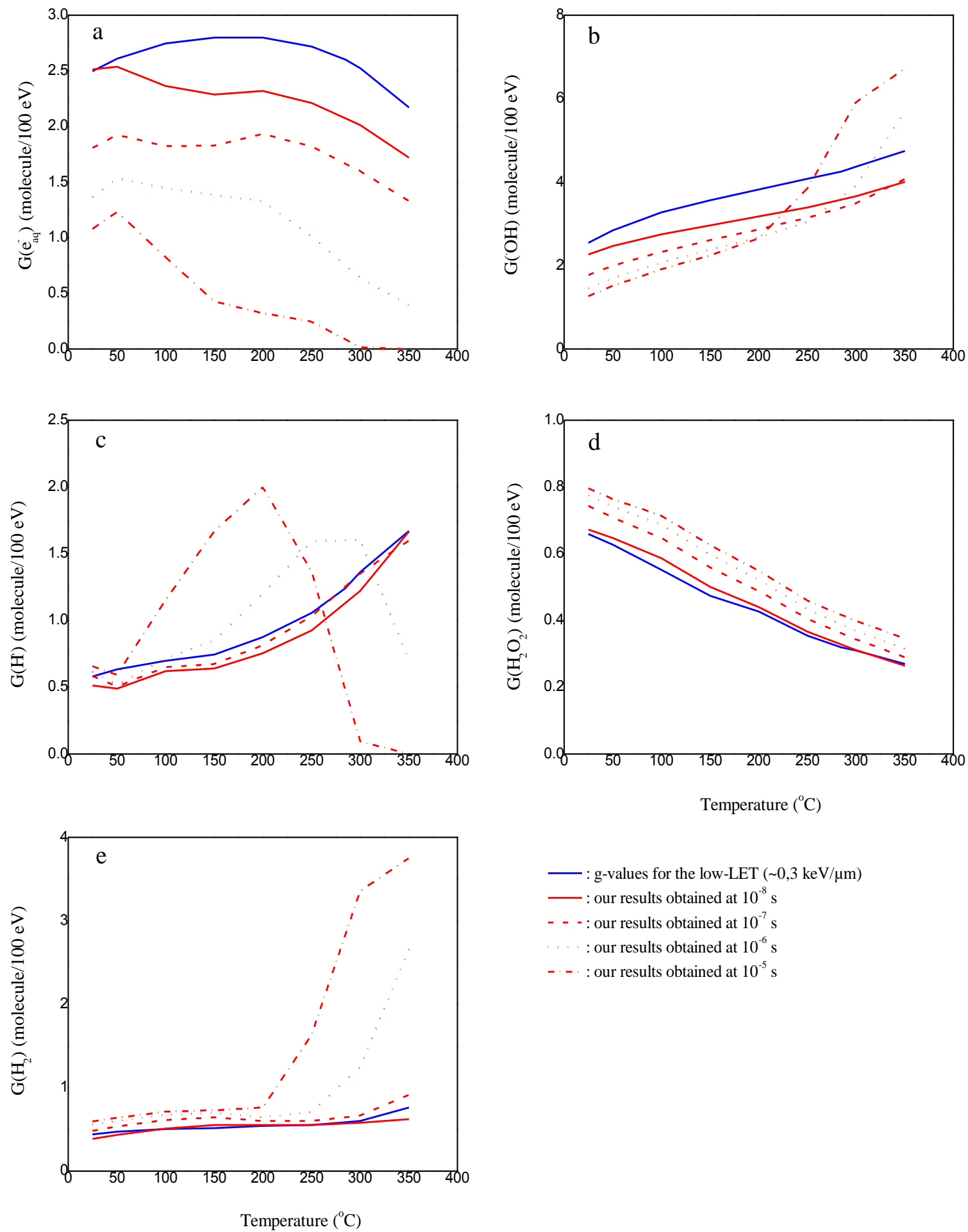

- - . : our results obtained at $10^{-5} \mathrm{~s}$

Figure 1. The $G$ (values) (molecule/100 eV) variation of water radiolysis by ${ }^{3} \mathrm{H} \beta^{-}$particle at temperature of $25-350{ }^{\circ} \mathrm{C}$; a $\left(\mathrm{e}_{\mathrm{aq}}{ }^{-}\right), \mathrm{b}\left({ }^{\circ} \mathrm{OH}\right), \mathrm{c}\left(\mathrm{H}^{*}\right), \mathrm{d}\left(\mathrm{H}_{2} \mathrm{O}_{2}\right)$ and e $\left(\mathrm{H}_{2}\right)$ 


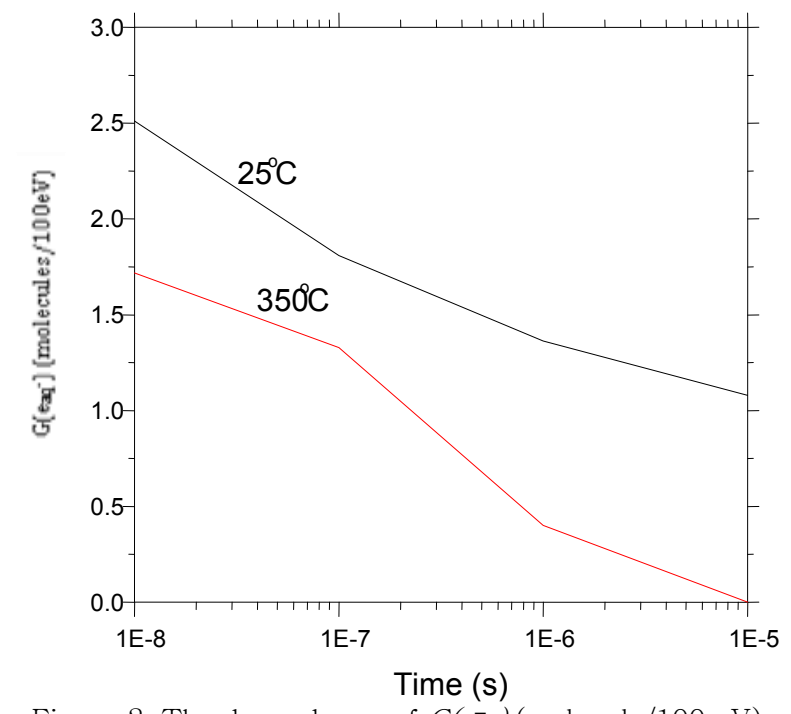

Figure 2. The dependence of $G\left(e_{a q}^{-}\right)$(molecule/100 eV) versus time at 25 and $350{ }^{\circ} \mathrm{C}$

The phenomenon is quite significant as seen in $\mathrm{G}\left(\mathrm{H}_{2}\right), \mathrm{G}\left({ }^{\circ} \mathrm{OH}\right)$ and $\mathrm{G}\left(\mathrm{H}^{*}\right)$. The $\mathrm{G}\left(\mathrm{H}_{2}\right)$ and $\mathrm{G}(\mathrm{OH})$ at $10^{-6}$ and $10^{-5}$ seconds increase above $200{ }^{\circ} \mathrm{C}$ and conversely the value of $\mathrm{G}\left(\mathrm{H}^{*}\right)$ declined. The phenomenon can be explained through the water oxidation reaction by atom $\mathrm{H}^{*}$.

$$
\mathrm{H}^{\bullet}+\mathrm{H}_{2} \mathrm{O} \rightarrow{ }^{\bullet} \mathrm{OH}+\mathrm{H}_{2}
$$

The reaction rate contribute significantly at temperatures above $200{ }^{\circ} \mathrm{C}$, however the value of the rate constant of this reaction remains unclear ${ }^{[17,18]}$.

According to reaction $\mathrm{R} 3$, it can be concluded that at higher temperature and longer time of the interaction between tritium $\beta$ low energy electrons with water, the presence of hydrogen atoms is reduced, while hydroxide species and hydrogen molecules in the water coolant increased. Although $\mathrm{H}_{2}$ is molecular products that are expected to decrease during temperature increase, but from Figure 2 could be seen that $\mathrm{G}\left(\mathrm{H}_{2}\right)$ increased sharply, especially at elevated temperatures and longer periods. This anomaly is caused by reactions between free radicals that are reactive with each other, namely the reaction among $e_{a q}^{-}$itself and the $\mathrm{H}$ atoms (Table 1). In addition, there are some reactions that contribute to ${ }^{\circ} \mathrm{OH}$. As the main oxidizer, the main reaction that forms and generates is $\mathrm{R} 4$

$$
e_{a q}^{-}+\mathrm{H}_{2} \mathrm{O}_{2} \rightarrow \cdot \mathrm{OH}+\mathrm{OH}^{-}
$$

Figure 3 (a) and (b) shows the reactions that contribute to the formation of $\mathrm{G}$ (values) of $\mathrm{H}_{2}$ and $\mathrm{H}^{\cdot}$ that are obtained at $10^{-7}$ and $10^{-6}$ seconds. Reactions contained in this graph is obtained from IRT module. Clearly, there was an increase in $\mathrm{H}_{2}$ caused by reaction R3. In terms of $\mathrm{H}_{2}$ formation rate, compared to other reactions, reaction $\mathrm{R} 3$ contribute approximately ten times. While the rate of $G\left(\mathrm{H}^{*}\right)$ formation is much less than the decay rate or its consumption, the value decreases with increasing temperature. Figure 3(b) describe clearly that reaction R3 have a significant influence at temperatures above $200{ }^{\circ} \mathrm{C}$. The significant correlated phenomenon is seen in $\mathrm{G}\left(\mathrm{H}_{2}\right), \mathrm{G}\left({ }^{\circ} \mathrm{OH}\right)$ and $\mathrm{G}\left(\mathrm{H}^{*}\right)$. Meanwhile, hydrogen peroxide $\left(\mathrm{H}_{2} \mathrm{O}_{2}\right)$ as the main corrosion products which lead to the alloy material degradation, the main reaction exist is a self reaction of hydroxide
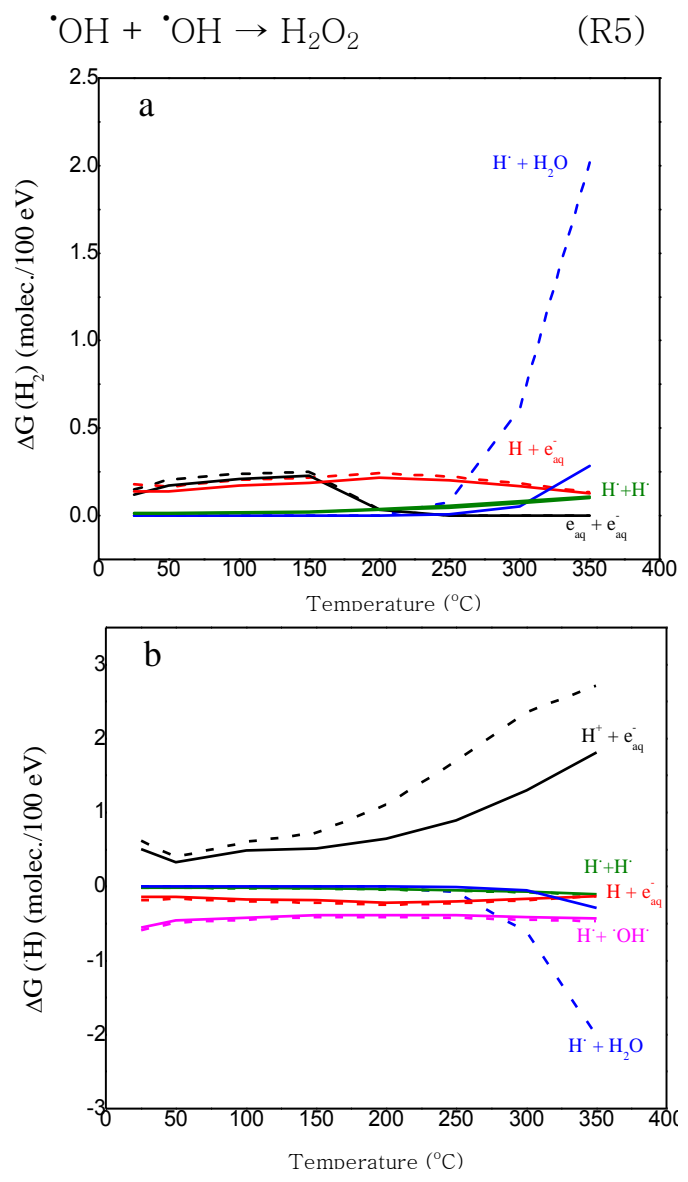

Figure 3. The $\Delta G$ (values) (molecule/100 eV) variation with temperature : (a) $\Delta G\left(\mathrm{H}_{2}\right)$ and (b) $\Delta G\left({ }^{*} \mathrm{H}\right)$ for the ${ }^{3} \mathrm{H} \quad \beta^{-}$particle at temperature of $25-350{ }^{\circ} \mathrm{C}$ at $10^{-7}$ seconds (solid line) dan $10^{-6}$ seconds (dotted line) 


\section{CONCLUSIONS}

The temperature influence on $G$ (values) of species radiation results by ${ }^{3} \mathrm{H} \beta-$ particle has a similarity with the low-LET $\left({ }^{60} \mathrm{Co} \gamma^{-}\right.$ rays). As temperature rises, $\mathrm{G}\left(e_{a q}^{-}\right)$and $\mathrm{G}\left(\mathrm{H}_{2} \mathrm{O}_{2}\right)$ decrease. With the increasing of temperature, the $\mathrm{G}\left(\mathrm{H}^{*}\right), \mathrm{G}\left(\mathrm{H}_{2}\right)$ and $\mathrm{G}\left({ }^{\circ} \mathrm{OH}\right)$ increase as well at $10^{-8}$ and $10^{-7}$ seconds, but at $10^{-6}$ and $10^{-5}$ second a significant difference is seen in $\mathrm{G}\left(\mathrm{H}_{2}\right)$, and $\mathrm{G}\left({ }^{\circ} \mathrm{OH}\right)$ that increased at temperatures above $200{ }^{\circ} \mathrm{C}$ and vice versa $\mathrm{G}\left(\mathrm{H}^{*}\right)$ is reduced in these conditions.

\section{ACKNOWLEDGEMENTS}

The author would like to appreciate thank you very much to the support of Center for Nuclear Reactor Technology and Safety, BATAN in DIPA 2016, which has funded this research and also to Professor Jean-Paul JayGerin for the Monte Carlo Simulation.

\section{REFERENCES}

[1]. S. Sanguanmith, et al, "Low-Linear Energy Transfer Radiolysis of Liquid Water at Elevated Temperatures up to 350 'C: Monte-Carlo Simulations." Chemical Physics Letters Vol. 508. pp. 46., doi:10.1016/j.cplett.2011.04.059, 2011.

[2]. L. C. Sophie. "Water Radiolysis: Influence of Oxide Surfaces on H2 Production under Ionizing Radiation." Water, Vol. 4, pp. 235-53, 2011.

[3]. Bartels, David M, et al. "Modeling the Critical Hydrogen Concentration in the AECL Test Reactor." Radiation Physics and Chemistry Vol 82 (1). pp. 16-24, 2013.

[4]. Christensen, Hilbert. "16 Fundamental Aspects of Water Coolant Radiolysis", SKI Report, April, 2006.

[5]. Elliot, A.J, et al. "Temperature Dependence of G Values for H2O and D2O Irradiated with Low Linear Energy Transfer Radiation." J. Chem. Soc. Faraday Trans. Vol 89 (8), 1993.

[6]. LIN, M., ET AL, "Pulse Radiolysis Studies on the Temperature-Dependent Spectrum and the Time-Dependent Yield of Solvated Electron in Propane-1,2,3Triol." J. Phys. Chem. A 113: 12193-98, 2009.

[7]. Sunaryo, G.R., et al, "Radiolysis of Water at Elevated Temperatures-II. Irradiation with Y-Rays and Fast Neutrons up to $250^{\circ} \mathrm{C}$." Radiation Physics and Chemistry Vol 45 (1), pp 131-39, 1995.

[8]. Butarbutar, S.L, et al. "Calculation of the Yields for the Primary Species Formed from the Radiolysis of Liquid Water by Fast Neutrons at Temperatures between 25-350 oC." Radiation Research Vol 181, 2014.

[9]. Butarbutar, S.L. et al, "Self-Radiolysis of Tritiated Water. 2. Density Dependence of the Yields of Primary Species Formed in the Radiolysis of Supercritical Water by Tritium B-Particles at 400 _C." RSC Adv. Vol 4, 2014.

[10]. Mustaree, S., et al. "Self-Radiolysis of Tritiated Water. 3. The $\mathrm{cOH}$ Scavenging Effect of Bromide Ions on the Yield of $\mathrm{H} 2 \mathrm{O} 2$ in the Radiolysis of Water by 60Co G-Rays and Tritium B-Particles at Room Temperature." RSC AdV, Vol 4, 2014.

[11]. Mirsaleh Kohan, L., et al. "SelfRadiolysis of Tritiated Water. 1. A Comparison of the Effects of 60Co $\mathrm{\gamma}^{-}$ Rays and Tritium $\beta$-Particles on Water and Aqueous Solutions at Room Temperature.” RSC Adv. Vol 3, 2013.

[12]. Meesungnoen, et al. "Yields of $\mathrm{H}_{2}$ and Hydrated Electrons in Low-LET Radiolysis of Water Determined by Monte Carlo Track Chemistry Simulations Using phenol/ $\mathrm{N}_{2} \mathrm{O}$ Aqueous Solutions up to 350 ${ }^{\circ}$ C." RSC Adv. Vol 5 (94), 2015.

[13]. Mirsaleh Kohan, et al. "Effect of Temperature on the Low-Linear Energy Transfer Radiolysis of the Ceric-Cerous Sulfate Dosimeter: A Monte Carlo Simulation Study." Radiation Research Vol 181 (5), pp 495-502. 2014.

[14]. Mccracken, D.R., et al.. "Aspects of the Physics and Chemistry of Water Radiolysis by Fast Neutrons and Fast Electrons in Nuclear Reactors.”, 1998.

[15]. A.J. Elliot And D.M. Bartels. "The Reaction Set, Rate Constants and G- 
Values for the Simulation of the Radiolysis of Light Water over the Range 20 to $350{ }^{\circ} \mathrm{C} "$, Report AECL No. 153127160-450-001, Atomic Energy of Canada Limited, Chalk River, Ontario", 2009.

[16]. D.M. Bartels. "Comment on the Possible Role of the Reaction $\mathrm{H}+\mathrm{H}_{2} \mathrm{O}-->$ $\mathrm{H}_{2}+\mathrm{OH}$ in the Radiolysis of Water at High Temperatures." Radiation Physics and Chemistry, Vol. 78, pp 191-94, 2009.
[17]. Swiatla-Wojcik, et al. "Reply to Comment on the Possible Role of the Reaction $\mathrm{H}+\mathrm{H} 2 \mathrm{O}-->\mathrm{H} 2+\mathrm{OH}$ in the Radiolysis of Water at High Temperatures." Radiation Physics and Chemistry, Vol 79 (1), pp 52-56, 2010.

[18]. Alcorn, C. Det al, "Kinetics of the Reaction between $\mathrm{H}$ and Superheated Water Probed with Muonium." Chem Phys Vol 435, pp 29-36, 2014. 
HALAMAN INI SENGAJA DIKOSONGKAN 